\title{
Suspect leptospirosis pada anjing lokal mix
}

\author{
Dodik Prasetyo*, Khoirin Nisa’ Irdiani Nanda Pamungkas \\ Departemen Klinik Hewan Pendidikan, Fakultas Kedokteran Hewan, Universitas Brawijaya
}

ABSTRAK: Anjing jenis lokal mix berumur 3 tahun dibawa ke Rumah Sakit Hewan Pendidikan Universitas Brawijaya dengan kondisi lemas, mukosa kuning. Pemeriksaan fisik menunjukkan bahwa anjing bernama chika mengalami lethargic, mukosa dan konjunctiva tampak ikterus suhu rendah $36^{\circ} \mathrm{C}$, capillary refil test $>2$ detik, dan mengalami dehidrasi. Hasil pemeriksaan radiografi menunjukan adanya hepatomegali dan pemeriksaan darah menunjukan kondisi anemia, serta neutrofil yang menunjukkan adanya infeksi bakteri. Pemeriksaan kimia darah menunjukan adanya gangguan pada hati. Diagnosis penyakit pasien ini adalah suspect leptospirosis. Terapi yang diberikan berupa antibiotik dan suplemen, namun pasien mengalami kematian setelah dilakukan perawatan selama 7 hari.

Kata kunci:

hati, ikterus, suspect leptospirosis, anjing lokal mix

\section{- PENDAHULUAN}

Leptospirosis dikenal sebagai penyakit zoonosis akut yang disebabkan oleh bakteri leptospira dengan spektrum penyakit yang luas dan dapat menyebabkan kematian (WHO, 2009). Gejala dan tanda leptospirosis yang tidak khas seperti demam, nyeri kepala, mual, dan muntah sering dianggap sebagai penyakit infeksi virus. Suhu dan kelembaban lingkungan yang tinggi merupakan kondisi ideal untuk kelangsungan hidup leptospira, akibatnya angka kejadian leptospira pada lingkungan tropis tinggi. Selain itu pada anak anjing, lebih rentan terinfeksi leptospirosis dibandingkan anjing dewasa apalagi bagi anjing yang belum divaksin memiliki tingkat kerentanan yang lebih tinggi untuk terinfeksis. Tulisan studi kasus ini mendeskripsikan seekor anjing dengan diagnosa suspect leptospirosis yang ditangani di Rumah Sakit Hewan Pendidikan Universitas Brawijaya (RSHP UB).

\section{- KASUS}

Anjing jenis lokal mix bernama Chika berumur 3 tahun dibawa ke RSHP UB dengan kondisi lethargic, mukosa ikterus (Gambar 1A dan 1B), tidak mau makan, pernah dibawa ke dokter hewan karena seluruh mukosa berwarna kuning dan urin berwarna kuning, menerima pengobatan, dan sempat membaik namun kondisi Chika kembali menurun. Hasil pemeriksaan fisik menunjukkan mukosa dan konjunctiva ikterus suhu $36^{\circ} \mathrm{C}$, capillary refill test $>2$ detik, dan dehidrasi. Hasil pemeriksaan citra radiografi menunjukkan pembesaran pada hati dan lambung dalam kondisi kosong (Gambar 1C).

Hasil pemeriksaan hematologi menunjukan anjing bernama Chika mengalami anemia normositik hipokromik dan infeksi bakteri berupa jumlah sel darah putih dan neutrophil yang tinggi (Tabel 1). Sel eritrosit hipokromik anisositosis berupa ukuran sel darah merah yang beragam dan warna pucat. Leukosit menunjukan kesan jumlah sangat meningkat dan banyak ditemukan neutrofil jenis segmented.
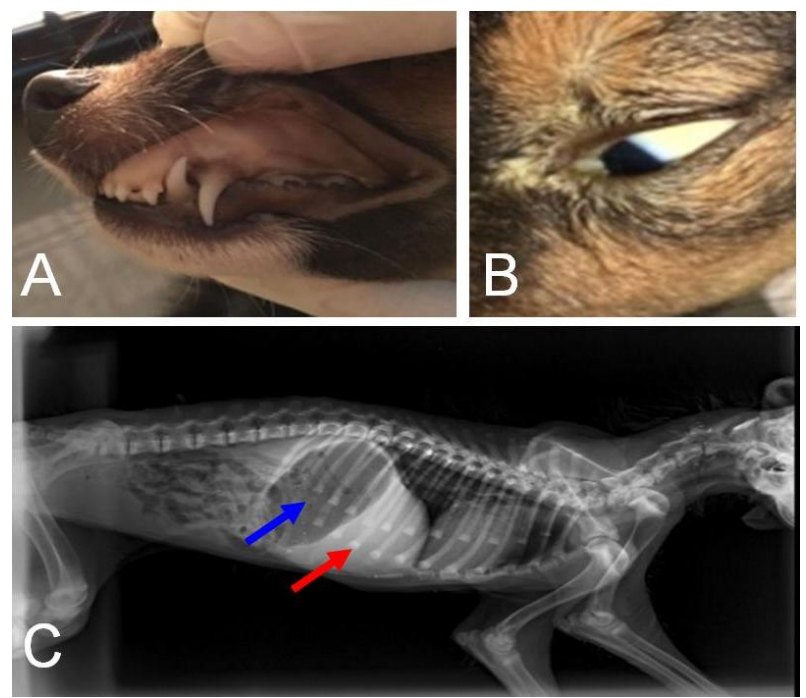

Gambar 1 (A) Mukosa mulut ikhterus, (B) Konjungtiva tampak ikhterus, dan (C) Radiografi organ dimana tanda panah merah menunjukan adanya hepatomegali dan tanda biru menunjukan lambung yang mengalami distensi dan kosong.

Pemeriksaan kimia darah menunjukan cholangiohepatitis dan gangguan ginjal (Tabel 2). Berdasarkan anamnesa, status present dan hasil pemeriksaan penunjang maka anjing didiagnosa suspect leptospirosis. Prognosa dubius-infausta. Treatment yang diberikan selama 7 hari berupa infus RL $150 \mathrm{ml} / \mathrm{IV}$, antibiotika Amoxiclav $20 \mathrm{mg} / \mathrm{kg}$ BB PO, Biodin $1 \mathrm{ml} \mathrm{IM}$, Urdafalk $1 \frac{1}{2}$ cap PO, Sari kurma 3 ml PO.

\footnotetext{
Diterima: 24-10-2018 | Direvisi: 19-11-2018 | Disetujui: 25-11-2018

(C) 2018 CC-BY-SA. Ini adalah artikel Open Access yang didistribusikan berdasarkan ketentuan dari Creative Commons Attribution ShareAlike 4.0 International License (https://creativecommons.org/licenses/by-sa/4.0/).
} 
Tabel 1 Hasil uji hematologi

\begin{tabular}{|l|c|c|l|}
\hline Pemeriksaan & Hasil & Standar & Keterangan \\
\hline WBC $\left(10^{3} / \mu \mathrm{L}\right)$ & 49,50 & $6,0-17,0$ & meningkat \\
$\mathrm{RBC}\left(10^{6} / \mu \mathrm{L}\right)$ & 1,56 & $5,5-8,5$ & menurun \\
$\mathrm{Hb}(\mathrm{g} / \mathrm{dL})$ & 2,8 & $12,0-18,0$ & menurun \\
$\mathrm{HCT}(\%)$ & 10,6 & $37,0-55,0$ & menurun \\
$\mathrm{MCV}(\mathrm{fL})$ & 68 & $60,0-77,0$ & normal \\
$\mathrm{MCH}(\mathrm{pg})$ & 17,8 & $19,5-24,5$ & menurun \\
$\mathrm{MCHC}(\mathrm{g} / \mathrm{dL})$ & 26,1 & $32,0-36,0$ & menurun \\
Platelet $\left(10^{3} / \mu \mathrm{L}\right)$ & 155 & $150-400$ & normal \\
Neutrofil $(\%)$ & 98 & $60,0-77,0$ & meningkat \\
Limfosit $(\%)$ & 1 & $12,0-30,0$ & menurun \\
Monosit $(\%)$ & - & $3,0-10,0$ & - \\
Eosinofil $(\%)$ & 1 & $2,0-10,0$ & menurun \\
\hline
\end{tabular}

Tabel 2 Hasil pemeriksaan kimia darah

\begin{tabular}{|l|c|c|l|}
\hline Pemeriksaan & Hasil & Standar & Keterangan \\
\hline AST/SGOT (IU/L) & 18 & $11-50$ & normal \\
$\begin{array}{l}\text { ALT/SGPT (IU/L) } \\
\text { Total bilirubin }\end{array}$ & 42 & $15-70$ & normal \\
(mg/dL) & 8,81 & $0,07-0,61$ & meningkat \\
$\begin{array}{l}\text { Direct } \text { bilirubin } \\
\text { (mg/dL) }\end{array}$ & 7,58 & $0,0-0,1$ & meningkat \\
$\begin{array}{l}\text { Indirect } \text { bilirubin } \\
\text { (mg/dL) }\end{array}$ & 1,23 & $0,0-0.3$ & meningkat \\
$\begin{array}{l}\text { ALP (IU/L) } \\
\text { Total Protein (g/dL) }\end{array}$ & 416 & $10-150$ & meningkat \\
$\begin{array}{l}\text { Albumin (g/dL) } \\
\text { Globulin (g/dL) }\end{array}$ & 1,5 & $2,4-7,5$ & menurun \\
Ureum/BUN & 3,5 & $2,7-4,4$ & menurun \\
(mg/dL) & 37 & $10-20$ & mormal \\
Kreatinin (mg/dL) & 0,3 & $1-2$ & meningkat \\
\hline
\end{tabular}

\section{- PEMBAHASAN}

Leptospirosis pada anjing selalu berkaitan dengan gagal ginjal akut dan penyakit hati yang disertai dengan jaundice. Beberapa kasus anjing leptospirosis menunjukan suhu tubuh rendah (hipotermia) dan dapat terjadi kematian sebelum kerusakan pada hati dan ginjal. Leptospirosis adalah penyakit zoonosis yang ditemukan di seluruh dunia. Penyakit ini disebabkan oleh genus leptospira, famili leptospiraceae, ordo spirochaetales (Mishima et al., 2013). Rodensia, terutama tikus merupakan hospes utama dari 10 jenis leptospira yang dapat menginfeksi manusia. Gejala klinis leptospira ditandai dengan fase akut atau fase septik yang dimulai setelah masa inkubasi berkisar antara 2-20 hari. Sedangkan fase kedua atau fase imun ditandai dengan meningkatnya titer antibody dan inflamasi di beberapa organ yang terinfeksi. Patogenitas leptospira yang penting adalah perlekatannya pada permukaan sel dan toksisitas selular. Lipopolysaccharide (LPS) pada bakteri leptospira mempunyai aktivitas endotoksin yang berbeda dengan endotoksin bakteri gram negatif, dan aktivitas lainnya yaitu stimulasi perlekatan netrofil pada sel endotel dan trombosit, sehingga terjadi agregasi trombosit disertai trombositopenia namun tidak terjadi DIC (disseminated intravascular coagulation) (Hickey \& Denners, 2002).
Bakteri dapat tersebar di beberapa organ tubuh antara lain ginjal, hati, sistem syaraf pusat, limpa, mata, dan organ reproduksi. Namun keberadaan leptospira di ginjal sulit dieliminasi, khususnya daerah glomerulus merupakan daerah yang jarang ditemukan antibodi karena ukuran antibodi yang tidak dapat melewati filtrat glomerulus (Hickey \& Denners, 2002).

Terapi yang dapat diberikan pada penderita leptospirosis berupa terapi kausatif dan suportif. Pemberian antibiotik pada hewan yang terinfeksi leptospira harus diperhatikan khususnya efisiensi obat dengan tujuan mempersingkat durasi penyakit, mengurangi penularan, dan menurunkan kerusakan hati dan ginjal. Terapi cairan pada penderita leptospira dimaksudkan untuk menangani dehidrasi yang terjadi akibat demam dan anoreksia. Selama masa pengobatan dan perawatan anjing chika tidak memberikan respon perbaikan yang signifikan dan cenderung mengalami penurunan berupa jaundice yang semakin jelas terlihat, suhu tubuh yang semakin menurun serta anoreksia. Chika mengalami kematian setelah dilakukan perawatan selama 7 hari. Kematian diduga akibat dari infeksi hepatorenal dan komplikasi bakteri leptospira yang menyerang beberapa organ. Angka mortalitas leptospirosis pada anjing mencapai 10-15\% (Major et al., 2014). Kematian paling sering terjadi akibat gagal ginjal, perdarahan dan ARDS (Acute Respiratory Distress Syndrome).

\section{SIMPULAN}

Berdasarkan gejala klinis dan didukung hasil pemeriksaan penunjang, menunjukkan adanya gangguan fungsi ginjal dan hati maka diagnosa untuk anjing lokal mix bernama Chika adalah suspect Leptospirosis. Terapi yang diberikan untuk memulihkan kondisi secara bertahap, mengurangi gejala klinis serta meningkatkan daya tahan tubuh. Meskipun tatalaksana pengobatan telah dilakukan dengan baik namun anjing tersebut mengalami kematian setelah 7 hari dirawat di RSHP Universitas Brawijaya.

\section{- INFORMASI PENULIS}

Penulis untuk Korespondensi

*DP: drh.dodik_prasetyo@yahoo.com

Departemen Klinik Hewan Pendidikan, Fakultas Kedokteran Hewan, Universitas Brawijaya

\section{- PUSTAKA ACUAN}

Hickey PW, Denners D. 2002. Leptospirosis. Medicine J, 2:1-17. Major A, Schweighauser A, Francey T. 2014. Increasing incidence of canine leptospirosis in Switzerland. Int. J. Environ. Res. Public Health , 11: 7242-7260.

Mishima, N, Tabuchi K, Kuroda T, Nakatani I, Lamaningo P, Miyake M, Kanda S, Koizumi N, Nishiyama T. 2013. The first case in Japan of severe human leptospirosis imported from Vietnam. Trop Med Health, 41 (4): 171-176.

World Health Organization (WHO). 2009. Leptospirosis Worldwide. Wkly. Epidemiology. 